\title{
Financing Strategy for Modern Islamic Boarding School Al-Muwahidin Lelede in District Kediri, West Lombok
}

\author{
Salikin; Wildan; Joni Rokhmat \\ Master Study Program of Administration Education, Mataram University, Indonesia
}

http://dx.doi.org/10.18415/ijmmu.v6i4.1014

\begin{abstract}
The purpose of this study is to describe the financing strategy of Modern Al-Muwahidin Lelede Islamic Boarding School in the administration of education. This type of research is a qualitative study with Grounded Theory. This research was conducted for six months starting from November to April 2019. The types of data in this study are primary data and secondary data. In this study the data was obtained by conducting several techniques or in the form of research instruments, namely observation, interviews and documentation, so as to obtain the information needed. Data collection techniques carried out by interview, observation, and documentation. The results showed that: 1) Education funding at the Modern Al-Muwahidin Lelede Foundation was sourced from the Government, private sector and entrepreneurial results. Funds coming from the government in the form of Operational Assistance Funds (BOS), Poor Student Assistance (BSM), DBO, and Special Allocation Funds (DAK), while funds from the private sector can be in the form of donations from parents of students and donations from donors, as well as Funds for entrepreneurship include, among others, the results of the business of eating and drinking santri, the results of the cooperative business of santri, the results of the mini market business and the results of the foundation's productive land processing. 2) The use of education funds is to finance eight education standards which include: content standards, process standards, graduate competency standards, teacher and education personnel standards, facilities and infrastructure standards, management standards, financing standards, and education assessment standards. 3) Accountability realization of the use of the budget carried out with an orderly administration, orderly targets, and orderly time. All forms of income and expenses are recorded in a cash book, accompanied by proof of payment and reported in accordance with applicable procedures.
\end{abstract}

Keywords: Financing Strategy; Foundation; Modern Islamic Boarding School

\section{Introduction}

Modern Islamic Boarding School Al-Muwahidin Lelede is one of the Islamic educational institutions in Indonesia which generally organizes various educational units ranging from PAUD, Madrasah Tsanawiyah, and Madrasah Aliyah which are under one roof. The classic problem that often affects educational institutions, especially Islamic educational institutions in this country, is education funding. This has an impact on almost all other educational components, even though the cost of 
education is one of the components of instrumental input which is very important in the administration of education in schools or madrasas or education in Islamic boarding schools. In an effort to achieve educational goals, the cost of education has a very decisive role. There is almost no educational effort that can ignore the role of costs, so it can be said that without costs, the educational process cannot run optimally, both at the level of planning, program socialization, procurement of facilities, implementation, supervision, and evaluation, as well as other educational support instruments. Funding has an integral function in the implementation of boarding school activities. Islamic boarding school activities will not run if they do not have operational costs. The development of funding sources for Islamic boarding schools serves to develop quality boarding activities.

To meet the demands of eight minimum standards of education and all boarding activities, a significant amount of money is needed. The operational costs of boarding require the management to work hard to raise funds so that the learning process and boarding activities run as expected. Law No. 20 of 2003 concerning the National Education System Article 11 Paragraph 2 states that the government and regional governments must guarantee the availability of funds for the implementation of education for every citizen aged seven to fifteen years. Article 12, Paragraph 1 states that every student in each education unit is entitled to get scholarships for outstanding students whose parents are unable to pay for their education and get education costs for those whose parents are unable to pay for education for their children.

Each student is obliged to share in the cost of providing education, except for students who are exempt from these obligations in accordance with applicable laws and regulations. The source of funds for education funding at Al-Muwahidin Lelede Modern Islamic Boarding School was obtained from government assistance through BOS funds and other contributions both from students' parents, the community and donors. This is consistent with research conducted by Murtadlo (2016), Muhajirin (2012), Yakin (2014), Alhipni (2015), and Khuriah, et al., (2016). In general, in private education institutions the strategy to increase sources of funding cannot run well, there are even some educational institutions that rely on assistance from the government alone. The limited funds owned by an educational institution requires the management of the educational institution to be more creative, sensitive to opportunities, build relationships, and manage existing funds as well as possible. Responding to the limitations of Islamic boarding schools in terms of educational funding, the Modern Islamic Boarding School AlMuwahidin Lelede always has unique things in fulfilling education funding. The uniqueness of Modern Islamic Boarding School Al-Muwahidin Lelede in terms of financing lies in the sincerity of all staff in working.

In general, if you pay attention to the existence of the Islamic Boarding School Al-Muwahidin Lelede, you can find several advantages and uniqueness in it, including: 1) The management of the Islamic Boarding School prioritizes aspects of the family, educators and educators from internal families, and citizens the community around the lodge, as well as prioritizing competent alumni; 2) Organizing deeper learning about Arabic grammatical science (nahwu science) and English, even making it a characteristic of Al-Muwahidin Lelede Modern Islamic Boarding School; 3) Require all students to have memorized levels of the Koran in stages ranging from one juz to five juz as a prerequisite for grade promotion and graduation; 4) From the social aspect of the community, Modern Islamic Boarding School Al-Muwahidin Lelede grows and develops in the Lelede Village community where the population generally works as artisans and day laborers. Besides these uniqueness, the management of financing sources, utilization and accountability must be done as well as possible.

The establishment of Modern Islamic Boarding School Al-Muwahidin Lelede is based on Mr. Guru Muslih Kholil, S.I.P, M.H's concern for children who cannot continue their education to a higher level of education after graduating from elementary school. This is due to the low economic level of the community and high school fees. In the beginning, Mr. Guru H. Muslih Kholil, S.I.P, M.H was only 
limited to accommodating children to study religion, study the yellow books, and learn Arabic by forming an Islamic study club forum. At present the Modern Al-Muwahidin Lelede Islamic Boarding School is managing five fields of education such as: a) Children of Sholeh; b) Tsanawiyah Madrasah; c) Aliyah Madrasah; d) Majlis ta'lim; and e) Ma'had Ali, with 35 teachers and staff. Based on preliminary observations made by researchers, Modern Al-Muwahidin Lelede Islamic Boarding School is one of the private boarding schools that began to show its existence in the world of education. The enthusiasm of the people who send their children to the Al-muwahidin Lelede Modern Islamic Boarding School has increased from year to year.

The data shows that in 2015 there were 176 students, in 2016 there were 216 students, and in 2017 there were 260 students. This public interest is caused by many factors, including: Pondok Messageren Modern Al-Muwahidin Lelede has been able to manage education well; able to carve out brilliant achievements in the academic field; Al-Muwahidin Modern Islamic Boarding School alumni were able to become leaders in the midst of society; have good English and Arabic language skills; have adequate study space; Have a safe and comfortable hostel; able to apply high discipline for teachers, staff and all students; and have the ability to develop good fundraising or philanthropic strategies. This data was revealed by Mr. Guru H. Muslih Khalil, S.I.P, M.H as the leader of Al-Muwahidin Lelede Modern Islamic Boarding School. The same statement was also expressed by Munawar, S.Pd.I as treasurer of the foundation. Munawar, S.Pd.I said that in the academic field the students were no less compared to other schools which were equivalent to their grade level, even in terms of English the students at AlMuwahidin's modern Islamic boarding school were far better when compared to students who are in public school.

To improve the quality of education and the quantity of facilities and infrastructure, the AlMuwahidin Modern Islamic Boarding School Foundation requires no small cost. In general, raising funds for education is very difficult for private schools, but for the Al-Muwahidin Lelede Modern Islamic Boarding School Foundation, raising funds is not too difficult. Data shows that in 2017 the Al-Muwahidin Modern Islamic Boarding School Foundation received a funding of Rp. 781,000,000.00 with a total of 260 students, while the other Islamic Boarding School Foundations such as: Al-Muslimun Islamic Boarding School Foundation NW Kebon Kongoq District Gerung obtained funds amounting to Rp $437,000,000.00$ with the number of students as many as 437 people. This data was provided by Zainul Irfan S. Pd, M.M as the principal of the AL-Muslimun Kebon Kongoq Vocational School. Likewise, the funds obtained by the Al-Mahsun Islamic Boarding School Foundation Dasan Tapen Gerung District, in 2017 received funds of Rp 120,000,000.00 with a total of 120 students. This data was obtained from information provided by Supilah S. Pd as treasurer of the foundation. Based on these data, the financing strategy of the Al-Muwahidin Lelede Modern Islamic Boarding School needs to be examined.

The purpose of this study is to describe the financing strategy of Al-Muwahidin Lelede Modern Islamic Boarding School in the administration of education. The purpose of this study in more detail is to describe: 1) Sources of funds for the administration of education at the Al-Muwahidin Lelede Modern Islamic Boarding School; 2) Management strategy of Al-Muwahidin Lelede Modern Islamic Boarding School obtains funding for education; 3) Components of spending on educational expenses in AlMuwahidin Lelede Modern Islamic Boarding Schools, 4) Accountability of education funding at AlMuwahidin Lelede Modern Islamic Boarding Schools.

\section{Metode}

This type of research is a qualitative study with Grounded Theory. Grounded theory is a type of qualitative method, where researchers can draw generalizations (what is observed inductively) abstract theories about the process of action or interaction based on the views of the participants studied (Sugiono: 
2015; 39). The approach used in this research is a qualitative descriptive approach and implemented at the Al-Muwahididn Lelede Modern Islamic Boarding School Foundation in Kebon Daye Indah Hamlet, Lelede Village, Kediri District, West Lombok Regency, West Nusa Tenggara.

This research was conducted for six months starting from November to April 2019. The types of data in this study are primary data and secondary data. In this study the data was obtained by conducting several techniques or in the form of research instruments, namely observation, interviews and documentation, so as to obtain the information needed. According to Arikunto (2013: 172) data sources are subjects from which data can be obtained. Data collection techniques carried out by interview, observation, and documentation. In the data analysis stage, the process begins by reviewing all data collected from various sources, namely from interviews, observations, official documents, and so on. Data analysis was carried out throughout the study and was carried out continuously from the beginning to the end of the study. Observation is not possible without analysis to develop theories based on data obtained.

\section{Results and Discussion}

\section{Sources of Funds for Providing Education in Al-Muwahidin Lelede Modern Islamic Boarding School}

Based on data from researchers' interviews with several sources and various other sources such as photos and written documents, it was found that, at the moment, the Modern Al-Muwahidin Lelede Islamic Boarding School has several sources of funds, namely: First, funding from the government through BOS, BSM, BOP, DAK funds. Susiana, (2016) explained that the source of funds from the central government came from the State Budget (APBN) both to finance routine activities listed in the Activity Entry List (DIK) and to finance development activities listed in the Project Entry List (DIP) . In addition, at the school level there are funds from the central government in the form of School Operational Costs (BOS), the amount of which is determined by the characteristics of students and school levels. Sources of funds from local governments are derived from the Regional Revenue and Expenditure Budget (APBD) both Provincial and Regency / City Budgets. Funds from the APBD are used to support educational activities in the area concerned such as routine activities and development activities. Funds from local governments are realized in the form of Educational Operational Costs (BOP), the amount of which is determined based on the financial capability of the relevant local government.

The two sources of funding for Al-Muwahidin Lelede Modern Islamic Boarding School Education are from donors. Donors are very instrumental in helping the continuity of education and progress in Islamic boarding schools. Harsono, (2007) explained that education funding can be classified into 4 types, namely education costs sourced from the government, education costs sourced from the community / parents of students, education costs sourced from sponsors and companies and education costs sourced from educational institutions itself. At present Pondok Modern Al-Muwahidin has permanent donors and temporary donors. Donors continue to come from the founders of Islamic boarding schools and santri parents, funds from santri parents can be in the form of tuition fees and building construction donations, while non-permanent donors are always available every year even though the amount is not too much.

The third source of funds is entrepreneurship. Al-Muwahidin Modern Islamic Boarding School has a variety of business activities. Such as: santri cooperatives, santri kitchen management and mini market management. Although there are already many sources of funding, there are still many sources of funds that can be used as sources of funding that have not been done by the management. Among them is the use of vacant land into productive land, collaboration with the business world and the industrial world.

The fundraising from various sources is in line with the thoughts of experts as quoted from the following sources: According to Fattah (2012: 43) there are seven sources of school funding: parents, 
central government, community groups, local governments, the business world / industry, private sector, and funding from alumni. In line with the Government Regulation of the Republic of Indonesia Number 48 of 2008 concerning education funding, article 2 paragraph (1) funding for education is a joint responsibility between the Government, regional governments and the community. According to Jahari and Syarbini (2013: 82) in terms of fundraising, fundraising can basically be extracted from two sources, namely; a) originating from within the institution itself (internal), and 2) through external parties (external). Among others are; endowments, zakat, shodakah, grants, and other non-binding funds. Funds from the government can be in the form of; Education Development Fund (DPP), Special Allocation Fund (DAK), School Operational Assistance (BOS), Operational Assistance Fund (DBO), and Poor Student Assistance (BSM).

\section{Al-Muwahidin Lelede Modern Islamic Boarding School Foundation Strategy Obtains Funding for Education}

Planning is the first step in identifying all organizational needs. Planning determines what, where, when and how long it will be carried out, and how to do it. Financial planning of Islamic boarding schools is an activity to plan financial resources to support educational activities and the achievement of educational objectives in Islamic boarding schools. planning as a systematic activity, meaning planning includes several stages of activity. One activity becomes the foundation for the next stage. Stages of the activity can be used as a guide so that irregularities can be immediately identified and addressed. While the purpose of planning itself is the direction so that the activities carried out do not deviate from the specified direction. To find out financial planning at Al-Muwhidin Lelede Modern Islamic Boarding School, researchers conducted interview methods and documentation studies in digging up information. This information was obtained from informants directly involved in the implementation of financial management in Islamic Boarding Schools, namely: Mr. Guru H. Muslih Khalil, S.I.P, M.H. Munawar, S.Pd.I, and Safri Usman, S.Pd.

In making financial planning for Islamic boarding schools, the board of the Al-Muwahidin Lelede Islamic Boarding School made the Islamic Boarding School Budget Plan (RABPP) as a plan formulated by the education unit according to its authority, carried out by a team specifically formed by the mudir ma'had of Islamic boarding schools with the committee known school and also santri parents. The making of the RAPBP (Pondok Revenue and Expenditure Budget Plan) is carried out in conjunction with the making of the RAPBM (Madrasah Revenue and Expenditure Budget Plan) with a bottom up system, namely the proposed budget for activities from below (teachers and employees) and approved by superiors namely the leadership of Pondok Pesantren Modern Al- Muwahidin Lelede. The financial planning process of Al-Muwahidin Lelede Modern Islamic Boarding School is carried out by the head of each madrasa and their staff, although the process is followed, supervised and authorized by Mudir Ma'had Pondok Pesantren.

All activities at Al-Muwahidin Lelede Modern Islamic Boarding School are interrelated with one another, for example, such as teaching and learning activities in madrasas, it is also inseparable from a series of other cottage activities, such as activities in the hostel, in the mosque, in the field, and the needs in public kitchens and others, so that this situation greatly affects the financial planning process which in the implementation of financial planning for Islamic Boarding Schools is carried out together with financial planning in madrasas. Menutut Masditou, (2017) education funding is one of the central systems in education, financing is part of supporting the implementation of education because it involves the operational financing of education administration from the smallest to the large operational financing. Choosing a program is one strategy to obtain Foundation education funding. In choosing a program to be carried out for a year based on the objectives to be achieved by taking into account the estimated amount 
of funding sources that can be obtained and other resources, as well as existing human resources. Program of activities that reflect the achievement of the vision and mission of Islamic boarding schools.

In addition to choosing programs, identifying and mobilizing available resources is a good strategy in raising foundation funds. Identification is done by collecting data and information from various parties, which are then identified by Mudir Ma'had and the Madrasa Head. This data and information in the form of human resources, facilities and funds or costs. Program socialization and approaches with all groups also need to be carried out by the Foundation. The socialization was carried out to all members of the community, fellow Al-Muwahidin boarding school alumni, Gontor boarding school alumni, an approach also carried out towards members of the House of Representatives (DPR), inviting benefactors, forming foster parents, and building independent businesses and approaches towards people old guardian santri.

The foundation also needs to ask for financial assistance by reducing the amount of money requested, for example for land purchases, offering donors to make as much as $1 \mathrm{~m}$ so that donors feel that they can make a contribution even though the value is very small. Likewise with the construction of other buildings such as foundries, the same thing is done by asking for at least one sack of cement or infaq money by auction technique to prospective donors in the form of money in the amount of $\mathrm{Rp}$ $1,000,000.00$ per building. Offer to donors for special funding. For example, special financing for santri bathroom maintenance. Another strategy that needs to be done to obtain foundation funding is to conduct program socialization to certain groups that are consistent in that field. Program socialization is not only about introducing people to the community, but socialization needs to be done to people who really care and are consistent in that field. The socialization is carried out by visiting target schools that will continue their education to sanawiyah and Aliyah levels.

Submitting a proposal is one strategy to get education funding and has been done by many other foundations. The proposal is made and submitted as a form of request for funds both in the form of facilities and infrastructure as well as routine funds obtained from BOS funds which are poured in the form of a budget plan. The methods used in fundraising are in line with the fundraising principles mentioned by Abidah (2016: 170), namely: the principle of asking, connecting with others, selling, building trust and community relations, and saying thank you. Strategies in raising funds are also carried out by improving the quality of education. Trying to produce the best graduates by selling superior programs. The superior programs offered are a special attraction for prospective students and prospective donors. This kind of marketing strategy is in line with Kotler's opinion in Jahari $(2013 ; 158)$ that the elements of marketing strategy known as 7P are: 1. product, 2. price, 3. place, 4. Promotion, 5. people, 6. physical evidence and 7. Process.

Based on the analysis of these data, researchers can draw conclusions that raising education funds at the Al-Muwahidin Lelede Modern Islamic Boarding School can be done in various ways including: socializing programs, building relationships, reducing demand, promoting program socialization and marketing superior programs.

\section{Component of Education Expenditure Funds for Al-Muwahidin Lelede Modern Islamic Boarding School Foundation}

Based on data from interviews and accountability documents for the use of funds, the results are obtained that educational funds obtained from various sources have been used optimally for all needs and operational needs of education in the Modern Al-Muwhidin Lelede Islamic Boarding School. The analysis shows that the use of education funds is to finance eight education standards which include: content standards, process standards, graduate competency standards, teacher and education staff standards, facilities and infrastructure standards, management standards, financing standards, and education assessment standards. The realization of the eight education standards is realized in the form of land purchases, procurement of facilities and infrastructure, teacher salaries and education personnel, 
library development, purchase of stationery, maintenance and repair, subscriptions and services, trainer fees, daily repetition activities, and purchases of consumables. The allocation of education funds at Pondok Modern Al-Muwahidin Lelede is in line with Fattah's opinion (2012: 112) education funding is the amount generated and spent for various educational implementation needs which include: teacher salaries, teacher professional improvement, provision of study space facilities, improvement of space, procurement of equipment/mobilers, testing of tools and textbooks, office stationery (ATK), extracurricular activities, educational management activities, and supervision.

The use of education funds at Al-Muwahidin Lelede Modern Islamic Boarding School is also in line with Permendiknas No. 69 of 2009. This Regulation of the Ministry of Education regulates personnel costs and non-personnel operational costs including: the cost of school stationery, the cost of materials and consumables, the cost of maintenance and minor repairs, the cost of power and services, the cost of transportation or official travel, the cost of consumption, the cost of insurance, student coaching or extracurricular costs, competency test fees, industrial work practice fees, and reporting costs. The use of funds is intended for all program activities carried out in pesantren in the form of formal and non-formal activities.

\section{Accountability of Educational Implementation Funds at Al-Muwahidin Lelede Modern Islamic Boarding School Foundation}

From the results of research conducted by the author, it is proven that when Islamic boarding schools that try to manage finances institutionally rather than familially will experience progress and be able to maintain its sustainability. So far, Islamic boarding schools are considered as educational institutions that are lagging behind and unable to compete with formal education institutions in general because one thing has been discussed so far that the education system in Islamic boarding schools still tends to be classical and the pesantren management system is also considered as a weak point of pesantren, because as we know, many pesantren use closed management and are more likely to be familial so that everything related to pesantren finances is managed by the family. Nevertheless, the modern boarding school Al-Muwahidin Lelede tries to innovate and always improve the management of the boarding school.

In order to maintain its sustainability, the modern boarding school Al-Muwahidin Lelede always upholds the principles of transparency and accountability and togetherness because the foundation's management considers that the boarding school is not owned by individuals or private property but the boarding school is the property of all people. Accountability for the use of the budget is carried out in an orderly manner, in an orderly manner, and in an orderly manner. All forms of income and expenses are recorded and reported in accordance with applicable procedures.

\section{Conclusion}

Based on the discussion, it is concluded that: 1) Education funding at the Pondok Modern AlMuwahidin Lelede Foundation is sourced from the Government, private sector and entrepreneurial results. Funds coming from the government in the form of Operational Assistance Funds (BOS), Poor Student Assistance (BSM), DBO, and Special Allocation Funds (DAK), while funds from the private sector can be in the form of donations from parents of students and donations from donors, as well as Funds for entrepreneurship include, among others, the results of the business of eating and drinking santri, the results of the cooperative business of santri, the results of the mini market business and the results of the foundation's productive land processing. 2) The use of education funds is to finance eight education standards which include: content standards, process standards, graduate competency standards, teacher and education staff standards, facilities and infrastructure standards, management standards, 
financing standards, and education assessment standards. 3) Accountability realization of the use of the budget carried out with an orderly administration, orderly targets, and orderly time. All forms of income and expenses are recorded in a cash book, accompanied by proof of payment and reported in accordance with applicable procedures.

\section{References}

Abidah, A. 2016. Pundraising Strategy Towards Improvement of ZIS Management at Amil Zakat Institution in Ponorogo Regency. http://Jurnalstainponorogo.ac.id. Access: 02 March 2018.

Alhipni, A. 2015. LKMS Performance in Supporting Islamic Boarding School-Based People's Economic Activities (Darut Tauhid Islamic Boarding School Study and Darut Tauhid BMT, http://lib.ui.ac.id. Access: 17 March 2018.

Arikunto. S. 2013. Research Procedure A Practical Approach. PT Rineka Cipta.

Fattah, N. 2012. Economics and Education Funding. Remaja Rosada.

Harsono. 2007. Management of Education Funding. Yogyakarta: Pustaka Book Publisher.

Jahari dan syarbini.2013.Madrasa Management Theory, Strategy and Implementation. Alfabeta.

Khuriah, Zamroni dan Sumarno. 2016. Development of an Evaluation Model for Managing Islamic Boarding Schools: http://journal.uny.ac.id/index.php/jpep.

Masditou. 2017. Management of Education Financing Towards Quality Education. Jurnal ANSIRU PAI. 1 (2): 119-127.

Muhajirin. 2012. Management of Education Financing Sourced From the Community http://journal.unes.ac.id/sju/index.php/eduman, Access: 11 April 2018.

Murtadlo. 2016. Education Financing Strategies in Leading Private Madrasas. https://jurnaledukasikemenag.org/index.php/edukasiarticle/view/14/14 Access: 2 March 2018.

Susiana, 2016. Pattern of Management of Private Madrasah Ibtidaiyah Financing MIS Al-Jihad Medan Sunggal, Tesis. Medan: Pascasarjana Universitas Negeri Medan.

Yakin, N. 2014. Management Patterns of Al-Raisiyah Islamic Boarding School in Mataram City. Jurnal Studi. 18(1) Access: 17 March 2018 https://www.researchgate.netGusti.

\section{Copyrights}

Copyright for this article is retained by the author(s), with first publication rights granted to the journal. This is an open-access article distributed under the terms and conditions of the Creative Commons Attribution license (http://creativecommons.org/licenses/by/4.0/). 